\title{
Sounds of Youth in the Metropolis: \\ The Different Routes of the Hip Hop \\ Movement in the City of São Paulo.
}

\author{
José Carlos Gomes da Silva
}

This article focuses on different social practices and representations undertaken by youth affiliated to the hip hop movement in the city of São Paulo. I reconstruct the trajectory of this movement to which rap is affiliated and analyze relationships between making music and new forms of urban segregation. I add to the analysis data and information about saraus, new spaces for cultural production by youth that combine music and literature. Our main hypothesis is that there are continuities between the hip hop movement and the literatura marginal presented in the saraus. We recognize that in both these forms of cultural intervention, youth register their ideas and explain the way that they learn, experiment and react to urban segregation.

Rap arose as a novelty in the Brazilian musical scenario at the beginning of the 199os. The vocal-audio discourse that characterizes it caused splits in the world of popular music, which until then was dominated by adults. For the first time, the sounds and voices with their own inflections and jargon, peculiar to the youth in the urban suburbs and peripheries, became audible. But FM radio practically ignored rap, only a few programs led by DJs linked to bailes blacks [black dances] included it. The diffusion of a new musical proposal was guaranteed by a parallel system composed of small recording companies, community radio stations, outdoor shows and nightclubs.

In the 199os, youth also became a novelty for social scientists, because studies undertaken in the field of urban anthropology in the 1970 s and early 1980 s had not focused specifically on youth, although they were present on the urban scene. The bailes organized by the sound companies Chic Show, Zimbabwe and Black Mad, and shows by punk bands from the $\mathrm{ABC}$ region of Greater São Paulo were not, at the time, the subjects of ethnographies. Studies conducted by Caldeira (1984), Sader (1988), Niemeyer (1985) and Zaluar (1983) 
about the popular classes in fact reveal important aspects about political organization, the daily life of workers and the precarious nature of urban infrastructure. But these registrations only present the perspective of adults.

In the mid-198os, the leisure and musical productions of youth began to become the object of field research in the social sciences. Anthropology took the first step (Caiafa 1985; Vianna 1988; Costa 1993). The analyses that we present are inscribed in this tradition of urban studies that has a closer focus on the cultural production of youth. We reflect on data obtained in two studies. The first was undertaken during our doctoral studies at UNICAMP (1998). ${ }^{1}$ The second, still in its initial stages, is a study about the neighborhood Capão Redondo, ${ }^{2}$ in which part of the research is dedicated to saraus, a cultural practice of youth that has ties to the hip hop movement.

The study of rap revealed to us specific aspects of musical production. Unlike other well-known musicians who only sporadically used the city as a poetic motivation - as we find in Saudosa Maloca (Adoniram Barbosa) and Sampa (Caetano Veloso) - rappers continuously link their musical composition to daily experiences in the metropolis.

This is not a case of a "contemplative art," which is fruit of a momentary state of inspiration. It is more of an "aesthetic of profound corporal and participant involvement, in relation to both content and form" (Shusterman 1998: 63). The music that they produce can only be understood based on this condition, because the musical production is not an artistic experiment related exclusively to the acts of composition and execution. This musical practice is part of a broader experience that involves how the youths experience, interpret and act in the world. The native term for this posture is attitude.

Therefore, the act of making music in hip hop is not reduced to strict artistic experimentation. The composition and musical execution mobilize concrete social experiences. Our observations of the saraus at Vila Fundão and Cooperifa ${ }^{3}$ confirm that there are connections between this phenomenon

1 For an analysis of a rap discography see Silva (1998).

2 The project $O$ Capão Redondo nas vozes dos adultos e jovens: lutas políticas, produções culturais e segregação urbana na cidade de São Paulo (1978-2012) is being conducted with support from FAPESP - The Research Support Foundation of São Paulo, which is essential in creating the opportunity for us to meet our objectives. We thus propose to analyze social practices and representations of adults and youth in the past 25 years in the neighborhood of Capão Redondo.

3 The saraus represent a new modality of cultural intervention of youth in peripheral neighborhoods. There are three important saraus in the periphery of the Southern Zone of São Paulo, the Sarau 
and practices peculiar to the hip hop movement. The purpose of presenting a song or a poem during a sarau, or the performance of a break dancer or the presentation of a video-documentary, is to establish network of sociabilities, reinforce solidarities and share meanings related to the social experience. To go to a sarau is not to act as a spectator, but as a participant. It is in this active dimension, as we see, that the saraus are connected to the hip hop movement.

In this article we also accompany the trajectory of the hip hop movement in São Paulo from its emergence in the urban center in the mid-1980s to its inscription in the periphery in the mid-199os. During this period, a new standard of social-spatial segregation became hegemonic in the metropolis. The process of raising walls and the fortification of the city led to the end of the center-peripheral model (Caldeira 2000). The drainage of cultural life from the urban center was one of the most immediate consequences. The development of the hip hop movement has an intimate relationship with the rise of this new form of urban segregation. ${ }^{4}$ The shift of hip hop towards the periphery, impregnated it discursively with this reality, and the strengthening of new cultural practices are related directly with the new living conditions confronted by youth in the city.

\section{The hip hop movement in São Paulo}

Our analyses began, more specifically, in the mid-1980s, a time in which we located the first information about the presence of elements of the hip

\footnotetext{
do Binho, the Sarau da Cooperifa and the Sarau Vila Fundão. The encounters are weekly. The Sarau do Binho is held on Monday, that of Cooperifa on Wednesday and Vila Fundão Thursdays. The saraus arose embryonically, the events were first limited to encounters of poets in small bars. These spaces, marked by the stigma of marginality were, however, resignified. The encounters grew and now attract different artistic expressions. Theater groups, musicians, writers and visual artists participate regularly in the sessions. The literary production of the youth took on new life. By the end of the decade, a significant group of young writers identified with literatura marginal, as they entitled it. The frontiers between rap music and the marginal literature became increasingly more tenuous. Many writers and poets even maintain dual affiliation.

4 The contributions of Urban Anthropology are combined in this article to reflections made in the field of the Anthropology of Music (Merriam 1964; Seeger 1977; Oliveira Pinto 2001). In this subfield of knowledge, musical productions are conceived as organized systems of sound. The music made by different social groups is interpreted as systems of representation which refer to the way that societies organize themselves. Rap is analyzed here with a basis in these theoretical references and the context in which we move is that of the urban transformations found in recent decades in the city of São Paulo.
} 
hop culture in Brazil. ${ }^{5}$ At this time there was still an intense public life in downtown São Paulo. The Praça da República [Republic Plaza], the Vale do Anhangabaú [Anhangabaú Valley] and the Praça da Sé [Sé Plaza] were the sites of important political acts, many of them decisive for the consolidation of democracy in the country. Large department stores such as Mesbla and Mappim emerged as symbols of an expanding culture of consumption. The mixture of social classes and the diversity of subjects that passed through the streets assured the urban space a more democratic public life, ${ }^{6}$ despite the authoritarian government. The urban culture thus provided a breath of life. Popular musicians, mimes, repentistas, street salesman, political protests and musical shows converged to strengthen a plural urban space.

The hip hop movement appeared in this scenario. Unlike the small circle of "well informed youth" identified by Vianna (1988: 34) in Rio de Janeiro," in the São Paulo context the group was expressive. The youth responsible for the organization of a new phenomenon provoked bewildered reactions, because they presented new visual symbols and uncommon sounds. Most of the participants came from the peripheral neighborhoods, they usually met around mid-day, at lunch time. Young office messengers, office staff, store clerks and students were both artists and audience. Break dancing was the first element of the hip hop culture to gain visibility. It became a frequent practice on streets such as Dom José Gaspar and Barão de Itapetininga. The members of the so-called Gangues de Break [Break Gangs] had a number of things in common. In addition to their origins in peripheral neighborhoods, their cultural references were black music, more specifically pioneers of U.S. rap such as: Africa Bambaataa and Soul Sonic Force, Malcolm Maclaren,

5 The hip hop movement arose in the United States in the 197os. Since the beginning, the principle focus was to counter the violence of the streets imposed by gangs. It was in this universe that the basic elements of the movement were structured. Break dancing (street dancing), graffiti (visual expression) and rap (vocal; and audio expression) arose in an organized manner in the Bronx in New York City, as a response to the absence of alternatives for youths affected by the neoliberal transformations. According to Tricia Rose (1994), the young blacks, Caribbeans and homeless were the most directly affected segments.

6 The discussions about the importance of intense public life as an essential experience for the democratization of urban spaces is found in the studies of Jacobs (2000), Caldeira (2000) and Sennett (1988).

7 For an understanding of hip hop in Rio de Janeiro in the same period, there is the pioneer study by Hermano Vianna. The allusion to small groups, both of break dancers as well as of rap, which met at the Crepúsculo in Cubatão, confirm that in fact, in the mid-198os, hip hop was popular with only a small number of young people in Rio de Janeiro. 
Kurts Blow, Run DMC, Sugar Hill Gang, Boogie Boys, Break Machine, Grandmaster Flash and the Furious Five. The sound came from a boom box: a huge portable sound system.

In the 1980s, the hip hop movement was limited to break dancing. The collective organization characteristic of youth in this period was the gang. The gangs ${ }^{8}$ performed at the corner of Rua 24 de Maio with Dom José de Barros and in front of the Teatro Municipal. In Sept. 1984 the magazine Break that specialized in this genre reported, not without a certain surprise, the presence of the phenomenon. Only two issues were published, but they are still cherished relics among movement participants. The magazines described the history of the dance in detail, indicated the most characteristic steps and discussed the development of break in Brazil. The description of the performance of Funk Cia, the main break gang, is one of the few records that we have about the way that the youth appropriated the central spaces of the city.

Downtown São Paulo at mid-day; a crowd gathered around a group of youth who incredibly twisted all parts of their body to the sound of an electronic beat that came from a portable sound system. An electric wave appeared to be passing through dancers. Suddenly they stopped and began to "break" their bodies with impressive mechanical precision. The crowd loves it. The sound of Malcolm Maclaren substituted that of Herbie Hancock on the tape player. Funk Cia is now moving backwards, as if pulled by a mysterious force. The time has come for each one of them to do a solo, which are acrobatic and dangerous. This is when each dancer shows their best, spinning on the top of their heads, their backs, doing back flips and much more. After a final step in unison they stop - completely immobile. The performance was over. The audience was ecstatic and expressed this with applause and money. The small crowd knew that they had just seen a highly developed street art created by youths from the periphery. (Break, Sept.1984: 7) (emphasis mine).

8 In the U.S. context the term gang has a meaning opposite that of crew. The concept of a gang implies rivalry, hierarchy and violence, while the concepts of crew and posse emphasize cooperation and solidarity among groups. For this reason, the youth who are in transition to the hip hop movement abandoned the term gang and adopted the term crew (Toop 1991: 14). In São Paulo the breakers of São Bento recognized the negative implications of the term gang, but in relation to the stereotypes, they resignified it, transforming it into a category of identity. Nevertheless, among rappers in São Paulo, the term posse still has the original meaning. 
The rise of break dancing is related to a group of conflicts that marked black neighborhoods in the United States, especially those torn by urban violence in the late 1970s. At this time street gangs assumed a central role in the expansion of drug dealing and young people were involved. The hip hop movement was interpreted in this context as a positive reaction of black and Caribbean youth to the actions of the gangs. According to Rose (1994) the strategy consisted in countering violence with art. The symbol of this new attitude among Americans was Afrika Bambaataa, founder of the posse Zulu Nation, which is still a reference for Brazilian breakers and rappers.

The development of break in Brazil was not endogenous; it originated with ties and exchanges with the U.S. context. For this reason these references are necessary. With a box ${ }^{9}$ in hand, São Paulo breakers would organize a roda or circle. The characteristic element of the music is the break or the break beat or the funk beat supplied by electronic percussion, enhanced with cybernetic sound effects from synthesizers. The sound takes us to a futuristic universe complemented by the robotic movements and performances of the b-boys..$^{10}$ Even today the preferred music in the rodas de break [break dancing circles] are those recorded by the first generation of U.S. hip hop. The sounds provided by the electronic percussion provide the base upon which the breakers celebrate the dance. ${ }^{11}$

In the mid-1980s, the breakers would take the downtown streets at lunch time. The b-boys came from different points of the São Paulo periphery. Most of them took advantage of break dancing to channel their artistic expression.

We came with a box to the street and start breaking (...) We danced on Rua Marconi, in front of the Teatro Municipal and on the corner of Dom José de Barros with 24 de Maio. During the presentation, we would explain what it was about to the audience. And little by little it began to have a favorable repercussion, until invitations to shows, parties, dance academies and other proposals

9 The term box is used by the breakers to refer to the sound system that played music recorded on cassette tapes while they danced in the streets.

10 Break dancers. In the United States the term referred to young blacks and Latin Americans who break danced, the breaking boys. In Brazil the terms b-boy and b-girl were used exclusively to refer to the youth who break danced.

11 After this period, dominated by the experiences with electronics, the "musical bases" for breaking practically disappeared. This was one more reason for the b-boys to remain faithful to the pioneers: Booggie Boys, Kurtis Blow and Afrika Bambaataa. The new bases sought to preserve the break beat that sustained the dance movements. 
began flowing in. ( Nelson Triunfo, Break Dance, set., 1984)

But, (...) not everything was glory and happiness. At times, Funk e Cia. had problems with the law. The police told them [to stop dancing] to "circulate" and they wound up at the police station. The police argued that they were attracting too many people in the street and this would lead to theft (Nelson Triunfo, Caros Amigos no 3 1998: 29).

The declarations confirm that the performance of the breakers did not become legitimate without recurring confrontations. The conflicts were particularly sharp with storekeepers who called the police, alleging that breakdancing was harmful to business, attracted people considered dangerous - pickpockets, people who lived in the streets, for example - although even at the so-called bailes blacks, the group found difficulties. Some sound crews believed that the dance and the athletic clothes used by the b-boys clashed with the black aesthetic, for this reason, they tried to restrain them. The bailes blacks attracted the breakers because the music played by the DJs, both at the funk dances observed by Vianna (1988), and at the bailes blacks in São Paulo, were the same used by the rodas of dancers that gathered in the streets. The repertoire included classics from the first generation of U.S. rappers, the so-called old school. The contradictions resided in the issues of dance, dress, the locale of the performances, as Andrade observed.

The baile was an incentive for the appearance of break - dance from the ghettoes among the poor Brazilian youth, but it was perfected in the streets and later with the formation of the gangs, they came to be a possible impediment or a competitor to the attraction of the bailes. For example, the young breakers wore clothes that were barely or not at all appropriate for the chic 'bailes blacks', which at that time, required that the "guest" use "sport-chic" clothing. The breakers, in turn, used clothes for dancing [in the streets]: a jacket and sneakers. The other question is that the spectacle of the gangs stole attention from the spectacle of the shows at the bailes (Andrade 1996: 30).

Between the years 1982 and 1985 breakdancing became popular and won over other social segments. Through its presentation in films, such as Flash Dance, and music videos produced by Michael Jackson, the genre invaded middle class health clubs, the recording market and radio and television programs. During the fad, break began to be presented in front of a store at the 
Shopping Center Iguatemi, to attract customers. The young Black Juniors were responsible for the first phonographic recording of a young black music group ${ }^{12}$ in Brazil (Black Juniors, RGE, 1984). This process would only be revived more intensely in 1989 , when rappers awoke the interest of the recording industry, stimulated by the sound crews at bailes blacks.

Nevertheless, once the fad had passed and with the persistence of conflicts in the central region, negotiations with municipal government had the São Bento subway station identified as a space for break gangs. Isolated performances would still be held on downtown streets, but the conquest of their own space proved to be promising for youth who wanted to improve their dance. The São Bento station was a covered space, which allowed performing when it was raining. It was also removed from police control and the conflicts downtown. For this reason, it quickly became a breakers territory par excellence.

São Bento had existed since 1983-84, so, when it arrived in 87-88 São Bento was already a reference because the fad, the wave of breaking, had already passed and São Bento was a sanctuary for the movement that was rising. And everyone would go there to break (Clodoaldo - rap group Resumo do Jazz).

New gangs were appearing amid the more experienced groups. Among the most significant were the Back Spin, Crazy Crew, Nação Zulu and the Street Warriors. Although they specialized in their activity as dancers, the statements confirmed that some break groups came to undertake musical experiments and to record their own songs. This included the Black Juniors and the Electric Boogies, the leading musical expressions of break in Brazil. ${ }^{13}$

12 The category black music is used in Brazil to identify different generations of black musicians who translated to the local sounds an Afro-American popular music tradition that was situated in the continuity between soul music and funk. As Sheryl Keyes (1996) observed, these are the musical matrixes close to rap. The category black music includes Brazilian artists who recognize themselves in the AfroAmerican musical traditions. This is how a distinct generation of musicians was classified and classified themselves including: Tony Tornado, Jorge Benjor, Tim Maia, Cassiano, Hildon, Carlos Dafé, Banda Black Rio, Sandra de Sá, Lady Zu. Brazilian rappers have particular admiration for black music. This repertoire is a reference in the construction of the musical bases. Moreover, invited by Mano Brow, the singer Hildon gave a show in 2010 at the anniversary of the Sarau da Vila Fundão. The enthusiasm demonstrated by the young people was surprising, as they sang songs that were successful more than 30 years earlier.

13 The recordings of Nelson Triunfo and Funk Cia Se Liga Meu (TNT, 1990), is a bit ambiguous. Although the personal trajectory of the artist was linked to breakdance, on the CD, the aesthetic was restricted to the cover, because the songs were influenced by rap. 
Nevertheless, for most youth, the streets were the space for making music. In this case, the musical foundation was improvised with the beat $b_{0 x^{14}}$ or on subway-station garbage cans, a practice that became symbolic of a generation. This musical knowledge was even used to distinguish members of the first generation of the hip hop movement from those who came later:

When you hear someone saying that I banged on the can, it's because [that person] passed through São Bento (Markão - rap group DMN).

At São Bento the space was clearly divided among the gangs. Each group exercised symbolic control of its territory, forming the respective rodas around the box. If a disagreement needed to be resolved, they promoted rachas [rifts], establishing rivalries always disputed through dance. Nevertheless, although the conflicts should have been resolved in the plane of art, at times they became real conflicts. But, obviously, this was not the central reason for which the breakers met, to the contrary, the artistic expression wound up prevailing:

I began to go there and I saw that there was that thing of each one for them self. Each gang had its space, there were lots of disputes, real fighting and a lot of opportunity for everyone. That is when I began to exchange ideas with the kids, because the media came around and it was bad because no one spoke. Then I found out that the more radical guys were from the gang that I was part of, Back Spin. We had a meeting, to get together to improve things. Little by little respect was being created. First, Nação Zulu began to speak with Back Spin, then Crazy Crew and finally the Street Warriors. That's when it was possible to begin to do street festivals and there was more media and the recording deal with Eldorado. What was cool is that at this time no one knew rap, and when there was a show of ours, all the gangs would go help out. This was very important, we really learned, it was historic. (DJ Hum, Revista Pode Crê no 3, 1994: 18-19).

14 Reproduction of the electronic percussion and of the sound of the electric bass synthesized by the vocal chords of an MC. This technique was used to create the break-beats as support for the spokensong. In the absence of a musical base, the rappers used this reference. The beat box compensated for the absence of electronic percussion that was very expensive. It also allowed for improvisation in the context of the streets, but there are few rappers who have command of this art. 
At the end of the 1980's, São Bento attracted young artists such as Thaide, MC Jack, and the group Balanço Negro, who were originally break dancers, it was at this time that we identified a more intense transition towards rap. Bad Boy, for example, was a breaker, but was also a graffiti artist and rap singer. Other youth were exclusively graffiti artists, such as the Gêmeos. Finally, the space at São Bento, in the late 1980s, was no longer a space only for breaking. With the passage of time new trends were established:

There were participants in the hip hop movement who did not break dance, they only wanted to rap or only knew how to rap. They were rappers first. They were not breakers who became rappers, who became graffiti artists or became DJs, like DJ Hum, who danced break and began to play. They were rappers who wanted to have a space to also develop.

(Clodoaldo - rap group Resumo do Jazz).

In the late 1980s São Bento had, therefore, established itself as a transition space for the first generation of Paulistano rap. Due to the historic presence of the break dancers, the location came to be formally recognized by the government as the "space for breakers in the city." 15 The strong identification with break did not impede the formation of splits in the original group. Youth who wanted to undertake the other elements of hip hop, but especially rap, or who had difficulty in insertion, sought, at the end of the 1980s, new alternatives. At first, one group moved to the Clube do Rap, under the sponsorship of Chic Show. ${ }^{16}$ The statements confirm that this experience was important for the artistic development of the first rappers, because it allowed them to promote the musical productions and to have a stage experience. But the art of the streets would continue at the Praça Roosevelt. ${ }^{17}$

The presence of the breakers in the São Bento subway station gave rise to the first rap recording clearly identified with the musical universe of the streets. Issues of urban life were musically re-elaborated and became predominant in the repertoire of the first recording entitled Hip Hop Cultura de Rua

15 I am referring to the authorization from the Metrô [subway authority] for the breakers to use the space at the Station.

16 Pioneer sound crew that organized bailes blacks, records of the activities date back to the early 1970 .

17 I present details of this time in my doctoral thesis (Silva 1998). This article is limited to summary registers of these experiences at the new location and later in the periphery. 
(Eldorado 1988). The production included contributions of rap pioneers such as Thaide and DJ Hum, MC Jack, O Credo and Código 13. At the time, the song Corpo Fechado by Thaide and DJ Hum was played on FM radio stations and the duo began to participate in television programs. The recording Cultura de Rua sold approximately 60,ooo copies (Caros Amigos 1998: 10), projecting hip hop in unexpected places.

The content of the CDs that arose in the period, Hip Hop Cultura de Rua (Coletânea 1988), Código 13/MC Jack (Código 13 e MC Jack 1989) and Hip Rap Hop (Região Abissal, 1988) recorded daily experiences familiar to the urban center. The only exception at the time was the song Homens da Lei (Thaide and DJ Hum) that focused on police violence in the periphery. Issues such as drugs and racism were also considered in the first recordings, but in an ironic or satirical way as in Centro da Cidade and Cidade Maldita (MC Jack), Sistemão, Que Zica Zé and O Gueto (Região Abissal). Daily life in the urban center and its personalities were the preferred themes of the songs. It was a universe peculiar to the young people who worked as office-boys or who were members of a break gang. The words of the song Centro da cidade are exemplar:

\section{Center of the City}

MC Jack

(...)

Hundreds of people looking for a job

If they don't find one the nightmare doesn't end

Hare Krishnas preaching their point of view

Evangelicals with their bible talking about a life

Shows I see right in the city square

Downtown there's also the Praça da República

Punk, dark, rocked and function

The Centro of the city is a big heart

I see it all and say nothing

But I'm back to say thanks

I owe a lot to you Centro of the city

I see it all and say nothing,

But I'm back again to say thanks

It's part of my life I can't forget a second

Jack is my name and you will remember

São Paulo I wouldn't trade you for anyplace 
The reasons for the split of the hip hop movement at the São Bento Station and the consequent formation of a new group at the Praça Roosevelt appear in different interviews. We find that one of the consequences of the split was a loss of the centrality of the dance and the strengthening of the music. As in the United States, rap acquired greater visibility in the city of São Paulo. At times, those interviewed mentioned that the reasons for the separation included the secondary condition of some youth at São Bento. They say that the groups that came later had difficulty gaining acceptance. In other cases, they mention the need for artistic development more oriented to the music. The split promoted by JR Blow with the breakers is also seen to be an important factor. ${ }^{18}$ In any case it was an important moment in the history of the hip hop movement, because since then a segment more identified with rap opted for the space of the Praça Roosevelt, while the other, more faithful to dance, in the case of the breakers, remained at the São Bento Station.

In short time the group that migrated to the Praça Roosevelt had experiences that were decisive to the consolidation of Paulistano rap. ${ }^{19}$ Among the youth who moved to the new space we find leaders like JR Blow from the group Stylo Selvagem, Bad Boy, Lady Rap, DMN, MT Bronx, Personalidade Negra, Doctor MC's, Racionais MC's and MRN. ${ }^{20}$

The main musical product of this new grouping was the recording Consciência Black I (1989), soon followed by Consciência Black II (1992). A shift was also perceived at this time in the musical field. The influences of the second generation of U.S. rap, represented by the groups Public Enemy, Eric B. and Rakim and NWA were solidified. Following this trend, the Brazilian rappers left aside the daily problems of the urban center. Racial and ethnic issues and urban violence in the periphery gained importance. The musical

18 JR Blow is seen as one of the main leaders of the period, having contributed to the insertion of the hip hop movement in the underground spaces of the city. JR Blow died in an accident and MT Bronx paid tribute to him on his first album. The songs clearly express JR Blow's importance to the youth at the Roosevelt (LP Nova Era, MT Bronx, 1992).

19 The CD Consciência Black II (Zimbabwe 1992), reflects the trends that became hegemonic in rap in the 1990 .

20 Amid the experience at São Bento, the hip hop movement at the time had the support of a movement with a more diffused characteristic, the Movimento Hip Hop Organizado ( $\mathrm{MH} 2 \mathrm{O})$, an initiative of musical producer Milton Sales, who was a businessman and disk jockey. This experience led to demonstrations in city parks. The first, held in March 1989, in Ibirapuera Park, was symbolically considered as a founding moment of the movement (Andrade 1996). Other events followed in the Parque da Aclimação and in the Parque do Carmo. 
foundation became denser and the low sounds of the electric bass and electronic percussion began to accentuate the gravity of the issues presented. Collages of urban sounds - sirens, shots and voices made possible by the use of sampling - became part of a new texture. The group Racionais MC's took the leadership among the young followers of the hip hop movement, preparing for the national success they achieved in the 199os.

The Racionais MC's' CD Raio X do Brasil (1993), revealed rap's strength. The first hits, Fim de Semana no Parque, Homem na Estrada and Mano na Porta do Bar, definitively inscribed the new sound and the new political discourse. Rap became the dominant artistic element. The shows came to emphasize, in native terms, the message to be taken to the manos [brothers]. Graffiti became a decorative element on the stages. Break dancing rose in this context as an element of a choreographic nature. Rap groups such as Thaide and DJ Hum and the Racionais MC's maintained the b-boys in this position. Among the audience, the predominant attitude was to pay attention to the messages.

It was a time when it began to be characterized that a rapper could not appear to be content at a show. People made a point of going on stage, talking a lot, looking mean and not accepting any kidding around, in a true hardcore line (Markão - from the rap group DMN).

You began to see rap groups much more often with a book under their arm than with a $C D$ or music magazine. That is, I think that it was an important and politically necessary phase (...) on the other hand, we are still debating the musical impoverishment (Clodoaldo - rap group Resumo do Jazz).

Rap gained visibility and success due to the support of small recording companies created by sound crews from the bailes like Chic Show, Kaskatas, Zimbabwe, Black Mad. In the early 199os, the rap groups also began to present themselves in bailes promoted by some of the same sound crews. Live shows became frequent. The production of CDs increased, in this case, as an extension of the activities of the companies that promoted the bailes blacks. Some of them created independent labels, responsible for recording, production and distribution of $C D$. The initial decision to record rap music was not, however, easily accepted. The first recordings of the Racionais MC's by Zimbabwe (Coletânea Black I 1989) were marked by a sense of identification, which joined businessmen and musicians, but also by a tension over the 
results. The following statement attributed to William, a black businessman, and owner of Zimbabwe, is illustrative.

DJ Cri, producer of the tracks in the collection, remembered it as if it was today: "On that day when Milton [the manager of the Racionais] took the demo tape, we also took a tape deck and cable to William's office in Santana so we could listen. He thought it was really heavy. He said that it would be difficult to work with that. But William recorded it. He put it on the last tracks of both sides of the LP, but recorded it. He [explained] why he decided to risk it "I felt an obligation, because they expressed in the words things that I had lived during my childhood" (Caros Amigos, 1998: 10).

The phonographic recordings developed, therefore, from an organizational structure that originated in the bailes blacks. Very few recordings were sponsored by the big record labels. The activity, conducted like a business, obviously sought to earn profits, but there was an identification between the businessmen and the musicians due to their common origins, although this relationship was always a source of conflict. Until today, rappers question the contracts made at the time, as well as the monopoly control of the recording companies over the groups, problems related to promotion and the lack of investments.

\section{The posses}

In 1990, the posse Conceitos de Rua was founded in the Zona Sul, and became a symbol of a new moment in the musical experience of youth. From then on, young people in the periphery began to intensify their contacts with the group that had moved to the Praça Roosevelt. ${ }^{21}$ A new orientation for the hip hop movement was beginning. The posse Conceitos de Rua arose as an initiative of young residents of the neighborhoods Capão Redondo, Vale das Virtudes and Jardim Helga. Little by little, other posses were organized. In the Zona Norte, the Força Ativa was formed, which through DJ Paul, also maintained contact with the group at the Roosevelt. In Cidade Tiradentes, in the Zona Leste, the Aliança Negra, was organized, led by Frenilson, who also

21 According to Carlos, one of the organizers of the posse Conceitos de Rua, the meeting with the Sindicato Negro was marked by surprise because neither posse had knowledge of the other. Despite the rivalry between the break dancers, however, the meeting established mutual respect. 
frequented the Roosevelt.

An important model for the migration of the hip hop movement towards the periphery was the experience of Sindicato Negro [Black Union], an organization created at the Roosevelt. Although not unanimously accepted, the Sindicato Negro served as an inspiration for the organization of new posses. The experiences of the Sindicato was short-lived due to internal divisions, but the greater difficulties, according to those interviewed, were related to the ostensive control by the police. The police, acting with characteristic prejudice, did not recognize the proposals of the youth and interpreted them to be a gang. ${ }^{22}$

The experiences downtown from 1991-1994 involving Geledés - Instituto da Mulher Negra [The Black's Women's Institute] and the youth at the Roosevelt, were also important for the future hip hop movement. The alliance involved the incorporation of rappers to the space of the entity. The Geledés Institute decided to take in the rappers in order to fight the police persecution. The news of the murder of a young member of the hip hop movement, supposedly by a policeman at a subway station, accelerated the encounter. The Projeto Rappers [Rappers Project] was the organizing base. It called for involving youth in thematic workshops about sexuality, race and music. The video SOS Racismo and the magazine Pode Crê were products of this intervention. The journal circulated in 1993-1994 and specialized in promoting the hip hop movement. After the activities at the Praça Roosevelt died down, and the experiences with the Geledés Insitute, the posses located in the periphery established themselves as the main points of support for the musical practice of the rappers.

After 1991, the space at the Roosevelt began to lose its original meaning. The accidental death of JR Blow in 1990, the interest of some groups in the recording market, the Projeto Rappers Geledés, which attracted some youth, were some explanations given for the decline. In parallel to the

22 The members of the Sindicato Negro used the symbol of their posse on jackets and tee-shirts, but the police interpreted these elements as identification of gang membership. We know that gangs, hierarchical organizations each with a leader and a faithful retinue of followers, according to Whyte's (2005) classic description, were not found among Brazilian youth. Even quadrilhas, as groups of drug dealers are known in Brazil, do not have firm structures (Zaluar 2003). The concept of a gang in fact does not apply to hip hop. Nevertheless, the term gang continues to be used by the Paulistano police to discredit the youth. Recently, the police defined the symbol 1 da SUL - Capão-SP, created by the writer Férrez as "a new gang of criminals who operate in the Zona Sul." 
demobilization of the Roosevelt in 1991, posses located in the peripheral regions came to revitalize the hip hop movement. The emerging rap groups found shelter in these new locations, and since then, the action became decentralized and local issues directly influenced the music.

From that time on, the music recorded by the rap group Racionais MC's began to represent the understanding that youth in the periphery had of the urban reality. The group's popular success was certainly related to its aesthetically differentiated musical proposal, although the band members also became legitimate interpreters of social problems. The phrase supported by more than 50 thousand manos mentioned in Sobrevivendo no inferno, on the notes to the $\mathrm{CD}$ refers to this less visible political dimension. At the shows, between one song and another, Mano Brown addressed the fans in an improvised speech marked by sharp criticism of the system. The expression self-awareness that he used synthesized the native knowledge respected by the members of the hip hop movement. This knowledge, according to the youths' vision, was opposed to the information presented in the major media, which was considered misleading. It was in this context that so-called community radio stations also proliferated. They were committed to presenting the music, but also to information considered authentic.

From that time on, the rappers presented themselves as the chroniclers of the periphery, or that is, the spokesman of a reality that is silenced by the major media and ignored by government. The type of registration that they make of urban life is always personal, biographical. The music is presented as language in a broad sense, and cannot be understood if reduced only to sound structures. The musical foundation is forged by the audio code of the streets; slang, car horns, gunfire and bar talk. The rappers approximation to the community of speech with which they want to be understood is essential. Their disobedience of the norma culta reveals the intentions of an outlaw discourse that does not use standard Portuguese. It is a phenomenon that radicalizes a peculiar characteristic of popular music, that is, the conflict with the normative standards proposed by the way that music is taught in school. The street talk, in the language of the streets and the social drama experienced by the musicians, by the common people, are expressed in the letters of the songs. Tensions between the elements of Western artistic music, which emphasizes writing and traditional music based on orality, is present in the 
sound of various popular musical genres, ${ }^{23}$ such as samba, blues, tango and reggae. Rap inscribed itself in this context, through its radical approach to the contradictions peculiar to the universe of popular music.

The São Paulo rappers emphasize the local expressions characteristic of the common language of the favelas and chaotic streets in which they intended to be heard. The words Mano Brown repeated at many shows are a good example: for me success is to sing in the favela, in Carandiru [a massive state penitentiary in the city], in the prisons. The mention of poor neighborhoods in the lyrics shares this sentiment of belonging to the universe of the excluded. In this case, the message can only be singular, for this reason, the rappers refuse to sing the songs of other groups, even those that are famous. Children in the periphery, for example, may sing the music of the Racionais MC's, even in classrooms, but a rap group, even a beginning one, would never dare do this.

A so-called "cover" performance is therefore seen as incompatible with the philosophy of hip hop because, according to the dominant values, the strongest reason for being part of the movement is to be capable of taking a message to the manos and this needs to be authorial. Since the subjective experience is essential in the making of the music, those who did not grow up in the location have difficulty in becoming legitimate. Rappers understand that those who present issues they have not experienced do not deserve credit. ${ }^{24}$

A revealing example of the position assumed by rappers as chroniclers of daily life is the song Pânico na Zona Sul (Racionais MC's 199o). The text is a realistic narrative of the micro-political situations that the social sciences classify as "war zones." The problems of urban violence, registered by research institutes and which identify youths as the main victims of homicide, are interpreted in musical language. Lyrics about the alliance between vigilantes and corrupt police offers acting as paramilitary forces; the theme of delinquency as an ideological justification for the extermination of youth; firearms as instruments of violence, all reveal awareness of the dramatic urban reality. The title of the LP Holocausto Urbano (1992) could not have been more expressive. The song Pânico na Zona Sul is only a small synthesis of the atrocities that they experience and express in the form of rhythm and poetry.

23 My reference to this marked aspect of popular music is based on the discussions of Bastos (1996).

24 Tricia Rose (1994) discusses this problem in the U.S. context, based on the experience of the rapper Vanilla Ice, a young, white middle-class singer who found difficulty being accepted as a member of the hip hop movement. This was experienced in Brazil by Rio de Janeiro rapper Gabriel O Pensador. 
Pânico na Zona Sul [Panic in the South Zone]

Racionais MC's, LP Holocausto Urbano, 1992

Then, when the day gets dark, only those who come from there know what happen. It seems to me that ignorance prevails, and we...are alone.

No one wants to hear our voice.

Super confident, guns in hand, unlikely a witness will appear

You can believe, the truth is avoided, because who can guarantee my day after?

They call vigilantes, they kill, humiliate and take...random shots.

And the police show no desire, to resolve or find the truth.

Because it is simply...convenient.

Why would they help if they think we're delinquent?

The incidents go on without a problem.

Panic reigns in the Zona Sul.

We know that rap is a musical expression characteristic of the current moment of internationalization of culture, but it is also clear that this genre acquired specific characteristics in the Brazilian environment. Within the local framework it is presented as a discourse that defends life. Using distinct strategies, the musicians strive to prevent the identities of those who were killed from being erased or diluted in statistics. For this reason, we frequently see Mano Brown refer to himself in shows, or in the notes to CDs, by means of the expression the speaker here is just one more survivor. This is the sensation that one has in the São Paulo periphery if one lives beyond the critical period between 15 and 24 years of age.

But the periphery is also seen positively, as a symbol of identity. In São Paulo, the engaged local experience is materialized in the posses. They are autonomous organizations dedicated to the development of the characteristic elements of the hip hop movement and to political intervention on a more immediate level. Integrated by rappers, breakers and graffiti artists, these entities become essential to artistic learning. Before they present themselves at public events, the youth perform their music in the intimate circuit of the posses, or that is, they present them among the manos. Precisely because an individual's affiliation to the group is considered important, researchers of the hip hop movement conclude that the posses or crews are a response to the disruptive social processes, stimulated by the new conditions of urban life.

Identity in hip hop is deeply enrooted in the specific and local experience, in 
the tie to a local group or alternative family. The crews are a type of family forged from an intercultural bond, that, like the formation of the gangs, promote isolation and support in a complex environment and serve as a base for the new social movements (Rose 1997: 34)

The idea of belonging to the community and to the posse is present in the songs and in the notes to the CDs. The images about the periphery appear impressive. The part of the city that is the object of admiration is that which is within reach of sight and feeling. What is important in the metropolis are the networks of relationships woven on the most immediate plane. The metropolis is not understood as a totality. The song, Fórmula mágica da paz is in this sense exemplary, because it expresses the ambiguities that mark life there.

Fórmula Mágica da Paz [Magic Formula for Peace]

Racionais MC's

This (***) is a mined camp. How many times I thought of getting out

Of here, but, my area is everything that I have. My life is here and I can't leave.

It's easy to escape, but I won't go. I won't betray who I was, and who I am.

I like where I go and from where I came, the lesson of the

favela was very good to me.

Each place a place, each place a law, each law a reason and I always obey, in any jurisdiction, any area.

Jardim Santo Eduardo, Grajaú, Missionária, Funchal, Pedreira and Joaniza. I try to See what you need most.

Build a home or buy some clothes, a lawyer to free your mano.

On the day of the visit you said that I will send cigarettes to the crazies in the X.

So, like I was saying, good blood, this is no sermon, listen up:

I have the gift.

I know what it's like, its $\left(^{\star \star *}\right)$ partner, Hee, evil in the head all day. No clothes, no car, no job, no popularity, no place for fun, ain't got no money.

(...)

Messed up - neh?

No one's better than anyone else, absolutely, this speaker is just another

Survivor.

The opening phrase presents the peripheral neighborhood as a type of mined field. The desire to abandon the locale is presented as a possibility, but it is rejected because of a feeling of belonging. To leave the community implies giving up one's origins, for this reason the expression: I won't betray who I was, who I am. To stay in the community implies, however, paying attention 
to the laws that rule the neighborhood. The idea that these spaces are controlled by micro-powers is what makes them unique: each place a place, each place a law, each law a reason... and I always obey.

The new standard of urban segregation that came to rule in São Paulo in the mid-1980s reflects the defensive orientation of the elites in relation to public spaces. The raising of walls and the construction of fortified enclaves, investments in electronic monitoring, reclusion in closed condominiums, use increased violence as a justification. The abandonment of public spaces was accompanied by large investments. The ideal of housing, work and leisure behind walls, also reached the periphery. Vigilance and defensive attitudes are also part of the "war zones," which are at times located alongside the fortified enclaves (Caldeira 2000). As researchers, when we move through the unknown neighborhoods of the periphery, we experience this state of permanent observation.

However, the rappers also interpret the local reality from a broader perspective, because they understand that there is a situation common to the São Paulo periphery. With the expression periphery is periphery in any place (Sobrevivendo no inferno, 1998) they call attention to the "family air" inherent to the neighborhoods located in distant regions, but uniquely close in function to the urban landscape that joins them. For this reason no encompassing category is found in rap that can evoke the unity of the metropolis, only the category periphery is presented in contrast to that which denominates the system, the playboyzada, the tiozinhos and tiazinhas who live closed-in, in the fortified condominiums.

\section{On this side: the saraus}

The saraus radicalized the concept of posse as a special place for making art. They also deepened the principle of belonging to the periphery. In the Zona Sul of São Paulo today, more precisely in the sub-municipal district of Campo Limpo, which includes the neighborhoods of Capão Redondo, Jardim Ângela, Jardim São Luis and Campo Limpo there are three important saraus: Cooperifa, Vila Fundão and the Sarau do Binho. A sarau can be defined as a community space that brings together local artists each week. In a single session, we can find various forms of expression such as poetry recitals, either of original poems or those by consecrated Brazilian authors, presentations 
by rap, reggae or rock musicians, chronicles of daily life, short theater skits or round table discussions about violence, media, and hip hop. Youth literature has gained particular life. Young writers such as Férrez, Claudia Canto, Marcos Lopes, Sacolinha and Sérgio Vaz, whose reading public goes beyond the location, have not lost their original references and are frequently present.

In the Vila Fundão we studied an important sarau, although a relatively new one. The neighborhood is a region occupied by the very poor who have built precarious housing. It is a favela with minimal urban infrastructure. It is located at the top of a hill, and is cut by torturous streets. The residents live with the duality of prejudice and the affirmation of a local identity. The participation of militants from the hip hop movement and writers affiliated to marginal literature creates a synthesis of the formula that guided the constitution of the posses. The youth meet weekly to exchange messages, make art and reflect on social issues from their daily life. The three saraus serve as points of intersection in a diffuse network of artists that circulate in the periphery promoting cultural intervention. In this way, they reconstruct the thesis that on the other side of the walls there are only "war zones," marked by massacres, homicides and all kinds of violence, which justify the raising of the walls, the hegemony of the defensive architecture and the violent action of the police. The artistic production of the saraus reveals another side of the periphery. Music is also present in the weekly programming of the bar where the event is held. The activities are divided by musical styles. On Thursdays, there is mostly Afro-American music, reggae and rap, Fridays are reserved for MPB (Popular Brazilian Music), on Saturdays local pagode groups perform and on Sundays there is samba.

The saraus are important cultural references for a region that, particularly in the 1990s, was classified as the most violent in Latin America. The high homicide rates - youths are the most common victims - inspired the Caminhada pela Vida e pela Paz [Walk for Life and Peace], an important social movement organized by community associations in partnership with the Catholic Church. In 2010, on All Soul's Day, the 15th walk was held. Rappers were pioneers in denouncing violence in the region. Father Jaime Crowe, an Irishman who came to the location at the peak of the social movements, created the idea for the protest walk in 1995. The indignation at the need for so many masses for so many killed youth was what inspired the event.

The echoes of protest against the racism and urban violence are found in 
the words of the songs, in the poems, in the improvised films, in the literatura marginal. The artistic production is quite diverse. Current reality is now distant from the ideal first proposed by the posses, which were organized, according to Rose (1994), as a type of alternative family, because in them the youths found support and solidarity. Perhaps this model no longer applies to the saraus, but there is a connecting thread that joins the two practices. That is, the feeling of belonging to the periphery

When I first heard the expression do lado de cá [on this side] I admit that it took me a while to understand. The term currently refers to the site of the Vila Fundão (www.doladodeca.com.br). The reference could not be more expressive, it marks in native language the social-spatial segregation to which the young and poor blacks are submitted. It expresses the spatial-symbolic frontier that separates the included segments, those located on the other side of the Pinheiros River - the other side of the bridges Capela do Socorro, Eusébio Matoso and the one at Av. João Dias - from the excluded who live do lado de cá [on this side]. Rapper Mano Brown was an initiator of the reflection on urban segregation in music. He is still a regular visitor to the Vila Fundão. In the words of Fernandinho, the organizer of the sarau, he is simply one more survivor to frequent the space. And that is how we saw him behave, with complete discretion, without the glamour of a pop star.

The anthropological tradition allows us to affirm that music is in these contexts a mark of identity, an important diacritical sign. The pairing of identity-difference is constitutive of this reflection (Cohen 1974; Cunha 1984; Barth 1997). We can argue that in these urban spaces, built under the logic of segregation, music has allowed youth to recreate a sense of identity in the "war zones". From a political point of view, as Caldeira observed (2000), the violence that shook the country after redemocratization revealed the disjunctive character of Brazil's incipient democracy, or that is, at the time in which we conquered the right to the complete exercise of citizenship, in which the voices of the periphery could be heard, we built segregated spaces, we prepared rites of suspicion of the unequal and the different, we killed experiences of public life, heterogeneity and diversity. We sought only to live among equals, residing in monitored and guarded enclosures.

But the native conclusion is also pertinent, why - on the other side of the walls, in the "war zones" - are there reactions? To leave the final words to Mano Brown; we try to use music to provoke people, to dis cuss the issues. 


\section{Bibliographical References}

ANDRADE, Elaine N. 1996. Movimento negro juvenil: um estudo de caso sobre jovens rappers de São Bernardo do Campo. Dissertação de Mestrado, USP.

BARTH, Fredrik. 1998. “Os grupos étnicos e suas fronteiras”. In: P. Poutignat; J. Streiff-Fenart. Teorias da etnicidade. São Paulo, Ed. UNESP. pp. 187-227.

BASTOS, Rafael M. 1996. A “origem do samba” como invenção do Brasil. Por que as canções têm música. Revista Brasileira de Ciências Sociais, no 31: 156-177.

CAIAFA, Janice. 1985. Movimento punk na cidade: a invasão dos bandos sub. Rio de Janeiro: Zahar.

costA, Márcia R. 1993. OS. Carecas de subúrbio. Caminhos de um nomadismo moderno. Petrópolis: Vozes.

CALDEIRA, Teresa Pires do R. 1984. A política dos outros. O cotidiano dos moradores da periferia e o que pensam do poder e dos poderosos. São Paulo: Brasiliense.

CALdeIRA, Teresa Pires do R. 2000. Cidade de muros. Crime, segregação e cidadania em São Paulo. São Paulo: Editora 34-EDUSP.

COHEN, Abner. 1974. Costom and politics in urban Africa: a study of hausa migrants in Yoruba towns. London, Routledge \& Keagan, Paul.

CUNHA, Manuela C. 1985. Negros, estrangeiros. Os escravos libertos e sua volta à África. São Paulo: Brasiliense.

JACOBS, Jane. 2000. Morte e vida de grandes cidades. São Paulo: Martins Fontes.

KEYES, Cheryl L. 1996. "At the crossroads: rap music and its African nexus". Etnomusicology, 40(2): 222-248.

OLIVEIRA PINTO, Tiago. 2001. “Som e música. Questões de uma antropologia sonora”. Revista de Antropologia, São Paulo, 44(1): 221-286.

NIEMEYER, Ana Maria de. 1985. Lugar da pobreza: moradia e controle de espaço na favela de São Paulo, 1972-1977. Tese de Doutorado, Universidade de São Paulo - São Paulo.

MERRIAM, Alan P. 1964. The anthropology of music. Evaston: Nortwestern University Press.

ROSE, Tricia. 1994. Black noise. Rap music and black culture in contemporary America. London: University Press of New England Hanover \& London. ROSE, Tricia. 1997. "Um estilo que ninguém segura: política, estilo e a cidade pós-industrial no hip hop”. In HERSCHMAN, M.(org.), Abalando os Anos 9o. Funk e Hip Hop. Globalização, Violência e Estilo Cultural. Rio de Janeiro: 
Rocco. pp. 192-212.

SADER, Eder. 1988. Quando novos personagens entram em cena. Rio de Janeiro: Paz e Terra.

SEEGER, Anthony. 1977. “Por que os índios suya cantam para suas irmãs?” In:

G. Velho (org.), Arte e sociedade. Ensaios de sociologia da arte. Rio de Janeiro: Zahar Editores. pp. 39-63.

SENNETT, Richard. 1988. O declínio do homem público. As tiranias da intimidade. São Paulo: Companhia das Letras.

SHUSTERMAN, Richard, 1998. Vivendo a arte. O pensamento pragmatista e a estética popular. São Paulo: Editora 34.

SILVA, José Carlos G. 1998. Rap na cidade de São Paulo: música, etnicidade e experiência urbana. Tese de Doutorado, IFHC, Universidade Estadual de Campinas - Campinas.

VIANNA, Hermano. 1988. O mundo funk carioca. Rio de Janeiro, Jorge Zahar Ed.

TOOP, David. 1991. Rap attack(2). African rap to global hip hop. London: Serpent's Tail.

WHYTE, William F. 2005. Sociedade de esquina. Rio de Janeiro: Jorge Zahar Ed. ZALUAR, Alba. 1983. Máquina e a revolta. Tese de Doutorado. Universidade de São Paulo - São Paulo.

ZALUAR, Alba. 2003. “Gangues, galeras e quadrilhas: globalização, juventude e violência”. In: H. Vianna (org.), Galeras cariocas. Territórios de conflitos e encontros culturais. Rio de Janeiro: Editora UFRJ. pp.17-57.

\section{About the author}

I am currently a professor in the Department of Social Sciences at UNIFESP -Guarulhos Campus. I concluded my masters and doctorate at UNICAMP. For my masters, defended in 1990, I studied samba in the city of São Paulo. The study of rap was part of my doctoral work, concluded in 1998. I was a professor at the Federal University at Uberlândia from 1994-2008. During this period I conducted studies about the congada, focusing on traditional music of African origin. During a post-doctoral fellowship at UNICAMP (2006-2008) I studied the life trajectory and literary production of the writer Carolina Maria de Jesus. Undertaking studies in the fields of urban anthropology, popular music, youth and Afro-Brazilian culture. I am 
currently studying the neighborhood of Capão Redondo in the city of São Paulo. I focus on the political struggles and cultural productions of adults and youth from 1978 to 2012.

josecarlosgs@uol.com.br

Received 30 September, 2010, approved May 13, 2011 